\title{
A teenage girl with an untreatable nephrotic syndrome: Questions
}

\section{Marta Cognigni $^{1}$ (I) $\cdot$ Marco Pennesi $^{2} \cdot$ Giulia Pennesi $^{3} \cdot$ Egidio Barbi $^{1,2}$}

Received: 19 June 2020 / Accepted: 30 June 2020 / Published online: 27 July 2020

(C) The Author(s) 2020

\section{Case}

A 17-year-old girl was referred to our care due to periorbital and lower limb oedema, high fever and asthenia that had been persisting for over a week. The urine dipstick tested positive for proteins (4+). Urine analysis detected high levels in nephrotic range (1873 $\mathrm{mg} 24 \mathrm{~h})$ and blood tests showed hypoalbuminaemia $(1.1 \mathrm{~g} / \mathrm{dL})$, hyperlipidaemia (cholesterol $333 \mathrm{mg} / \mathrm{dL})$, hyperfibrinogenemia $(1394 \mathrm{mg} / \mathrm{dL})$ and high C-reactive protein (CRP $7.5 \mathrm{mg} / \mathrm{dL}$ ). A nephrotic syndrome (NS) was therefore diagnosed.

Abdominal and cardiac ultrasound, kidney Doppler study, chest X-ray and ophthalmologic evaluation, performed to rule out a TINU (tubulointerstitial nephritis and uveitis) syndrome, were normal.

Fractions of complement (C3, C4), autoantibodies (ANA, antiDNA, pANCA, cANCA, ENA), serology for HIV, HCV, $\mathrm{HBV}$ and toxoplasmosis were all in normal range.

A steroid treatment was started, and, since the age of onset was not typical for a minimal change disease, a kidney biopsy was performed, the results of which showed a focal segmental glomerulosclerosis (FSGS).

This refers to the article that can be found at https://doi.org/10.1007/ s00467-020-04708-y

Marta Cognigni

martacognigni@gmail.com

1 University of Trieste, Trieste, Italy

2 Institute for Maternal and Child Health-IRCCS Burlo Garofolo, Trieste, Italy

3 Edinburgh Napier University, Edinburgh, UK
Due to the persistence of both peripheral oedema and significant proteinuria after 1 month of treatment, an immunosuppressive therapy with tacrolimus was added. Over the following weeks not only no significant improvement was observed but the patient also developed long-lasting fever (15 days) and arthralgia.

In view of the age of onset, the atypical course of the disease and the symptoms developed while on immunesuppressive therapy a workup for secondary glomerulopathies was repeated: blood tests, blood cultures, viral markers, chest $\mathrm{x}$-ray and abdominal ultrasound were all normal except for increased CRP levels $(21.1 \mathrm{mg} / \mathrm{dL})$ and erythrocyte sedimentation rate (ESR) $(56 \mathrm{~mm} / \mathrm{h})$. Due to the persistence of the fever and the increased inflammatory parameters in a patient with otherwise normal laboratory tests, ultrasonography and $\mathrm{x}$-ray investigations, a total body magnetic resonance imaging (MRI) was performed to further investigate (Fig. 1).

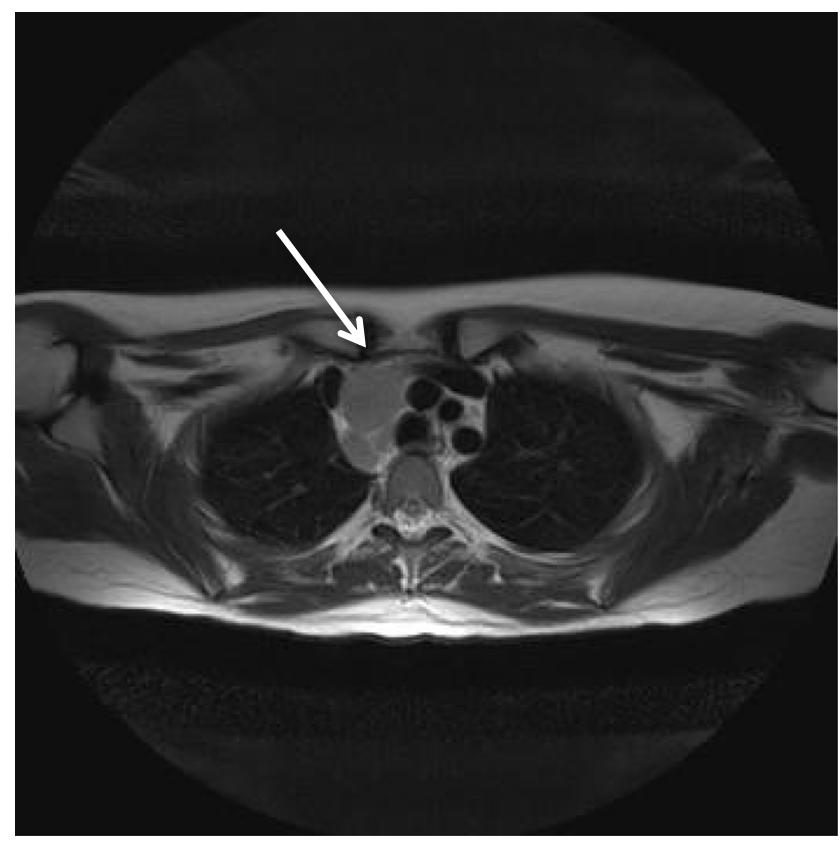

Fig. 1 Magnetic resonance imaging (MRI) sequence 


\section{Questions}

1. What is the most likely diagnosis?

2. Which are the clinical features suggestive of this condition?

3. What are the treatment and the prognosis of the disease?

Funding information Open access funding provided by Università degli Studi di Trieste within the CRUI-CARE Agreement.

Open Access This article is licensed under a Creative Commons Attribution 4.0 International License, which permits use, sharing, adaptation, distribution and reproduction in any medium or format, as long as you give appropriate credit to the original author(s) and the source, provide a link to the Creative Commons licence, and indicate if changes were made. The images or other third party material in this article are included in the article's Creative Commons licence, unless indicated otherwise in a credit line to the material. If material is not included in the article's Creative Commons licence and your intended use is not permitted by statutory regulation or exceeds the permitted use, you will need to obtain permission directly from the copyright holder. To view a copy of this licence, visit http://creativecommons.org/licenses/by/4.0/.

Publisher's note Springer Nature remains neutral with regard to jurisdictional claims in published maps and institutional affiliations. 